\title{
Carotid intima-media thickness and coronary artery Disease
}

\author{
Murari Prasad Barakoti \\ Correspoding Author: Murari Prasad Barakoti \\ Department of Cardiology, Gautam Buddha Community Heart Hospital, Butwal, Rupandehi, Nepal. \\ Email: drmuraribarakoti@gmail.com
}

\section{DOI: http://dx.doi.org/10.3126/njh.v15i1.19705}

It is known from the post-mortem studies of accidental death that atherosclerotic process begins in childhood and gradually progresses over decades. ${ }^{1}$ Only when the process leads to flow limiting stenosis as a gradual narrowing or when a thrombus forms at a site of plaque due to rupture or erosion, then the clinical cardiovascular event is manifested. ${ }^{2}$ Although only a certain percentage of people with underlying atherosclerosis become manifest, the greater degree of subclinical atherosclerosis is associated with greater chance of future events. ${ }^{3-6}$ The event could be sudden cardiac death at its extreme.

Hence there is a greater interest in identifying asymptomatic atherosclerosis process in an individual. They can be of candidate for intensive evidence-based medical interventions to reduce the risk of events. Imaging techniques is one way to define the cardiovascular risk assessment. However, the screening test should be cheap, safe, easy, and sensitive and should be decisive for the intervention that would change the natural history of the cardiovascular disease.

The ultrasound measurement of carotid intima-media thickness (CIMT) has withstood test of time as an important technique of measuring atherosclerotic burden. It has been more than three decades to know the value of CIMT in the risk prediction.

\section{Anatomy}

We are measuring the combined thickness of intima and media of common carotid artery of both sides. The right common carotid artery is a branch of innominate artery, also known as truncus brachiocephalicus, because it divides into common carotid artery (CCA) and subclavian artery. Left CCA directly originates from the aortic arch.

The cervical course of CCA is medially located, slightly behind the internal jugular vein. It then bifurcates into internal carotid and external carotid arteries approximately at the level of fourth cervical vertebra. ${ }^{7}$ It is superficially located, straight and relatively long caliber making its measurement relatively easy.

\section{Histologically there are three layers in the arteries:}

1. Tunica intima: inner layer of endothelial cells

2. Tunica media: middle layer of longitudinal smooth muscle cells surrounded by connective tissues

3. Tunica adventitia/ externa: outer layer lying in the circumjacent tissue

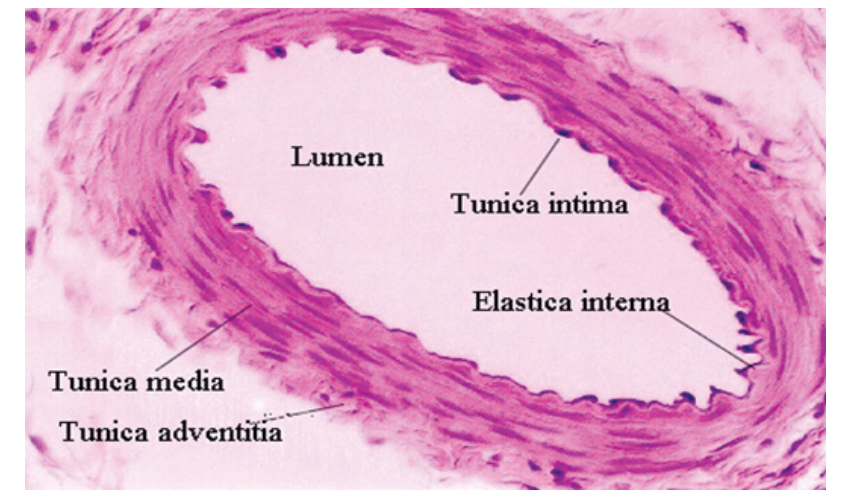

Fig 1: Histology of common carotid artery

\section{Histopathology}

Atherosclerosis process is regarded as systemic chronic inflammatory disease ${ }^{8}$; the major impact of morbidity and mortality of it being the cardiovascular disease. The process of atherosclerotic vascular disease is viewed in a theory called "response to injury theory". ${ }^{9}$ It says that a physical injury of endothelium is primarily responsible for the changes in vessel wall. ${ }^{10}$ In fact endothelial dysfunction is regarded as a functional trigger to atherosclerosis. LDL cholesterol gets in the endothelium and the following oxidative and enzymatic processes lead to series of changes that leads to different stages of development of atherosclerosis.

The early phase is hypertrophic response of medial cells, that can be assessed by carotid intima media thickness (CIMT) measurement and later stages are mostly carotid plaques caused by inflammation, oxidation, and smooth muscle cell proliferation. ${ }^{11}$ Increased CIMT is typically seen in common carotid artery due to its flow dynamics, whereas plaques are particularly seen in internal carotid artery or carotid bulbs. As found in the studies, CIMT elevation are most often related to hypertension and stroke as there is stronger relationship of carotid plaques at carotid bulb or internal carotid artery to dyslipidemia and myocardial infarction. ${ }^{12}$

\section{CIMT measurements}

Already in the 1980s Paulo Pignoli et al. could demonstrate a significant association between histological findings of in vitro study and ultrasound examination in the specimens. ${ }^{13}$ 
They described a characteristic B-mode image of arterial wall consisting of two parallel echogenic lines separated by hypoechoic space. The combined width of carotid artery intima and media can be reliably visualized in nearly all subjects. Since then multiple studies have been carried out to study the association of CIMT with cardiovascular risk factors, extent and severity of atherosclerosis and cardiovascular and cerebrovascular events.

\begin{tabular}{|c|c|c|c|c|c|c|c|}
\hline $\begin{array}{l}\text { Author } \\
\text { Year }\end{array}$ & $\begin{array}{l}\text { Study } \\
\text { Name }\end{array}$ & $\begin{array}{l}\text { No of } \\
\text { Participant }\end{array}$ & $\begin{array}{l}\text { Age of } \\
\text { participant }\end{array}$ & Primary Endpoints & $\begin{array}{l}\text { Measured } \\
\text { at }\end{array}$ & Risk Estimation & $\begin{array}{l}\text { Method of } \\
\text { measurement }\end{array}$ \\
\hline $\begin{array}{l}\text { Chambless } \\
\text { et al. } \\
1997\end{array}$ & ARIC $^{5}$ & 12,841 & $45-64$ years & $\begin{array}{l}\text { Fatal and nonfatal } \\
\text { CV events }\end{array}$ & $\begin{array}{l}\text { CCA, } \\
\text { CB, ICA }\end{array}$ & $\begin{array}{l}\text { For CIMT >1 vs. }<1 \mathrm{~mm}, \mathrm{HR} \\
1.18(1.06-1.32) \text { in men and } 1.42 \\
(1.24-1.64) \text { in women. } \\
\text { (Adjusted for Diabetes, HDL-, } \\
\text { LDL-cholesterol, hypertension, } \\
\text { smoking status, study center, age } \\
\text { and race) }\end{array}$ & $\begin{array}{l}\text { CIMT = } \\
\text { mean CIMT } \\
\text { from } 6 \\
\text { different } \\
\text { segments }\end{array}$ \\
\hline $\begin{array}{l}\text { O'Leary } \\
\text { et al. } \\
1999\end{array}$ & $\mathrm{CHS}^{6}$ & 4,476 & $\begin{array}{l}72.5 \text { years } \\
\text { (mean age) }\end{array}$ & $\begin{array}{l}\text { Myocardial } \\
\text { infarction, stroke, } \\
\text { combination of } \mathrm{MI} \\
\text { \& CVA }\end{array}$ & $\begin{array}{l}\text { CCA, } \\
\text { ICA }\end{array}$ & $\begin{array}{l}\text { RR-combined endpoint CCA: } 2.22 \\
(1.58-3.13) \text { for }>1.18 \mathrm{~mm} \text { (highest) } \\
\text { vs. }<0.87 \mathrm{~mm} \text { (lowest CIMT- } \\
\text { quintile); } 2.47 \text { (1.59-3.85) for } \\
>1.81 \mathrm{~mm} \text { (highest) vs. }<0.90 \mathrm{~mm} \\
\text { (lowest CIMT-quintile). } \\
\text { (Adjusted for age, gender, blood } \\
\text { pressure, smoking, Diabetes, atrial } \\
\text { fibrillation) }\end{array}$ & Max. CIMT \\
\hline $\begin{array}{l}\text { Del Sol et al. } \\
2002\end{array}$ & Rotterdam ${ }^{14}$ & 1,721 & $>55$ years & $\begin{array}{l}\text { Stroke, Myocardial } \\
\text { Infarction }\end{array}$ & $\begin{array}{l}\text { CCA, } \\
\text { CB, ICA }\end{array}$ & $\begin{array}{l}\text { RR } 1.41(1.25-1.82) \text { for stroke and } \\
1.43(1.16-1.78) \text { for myocardial } \\
\text { infarction }\end{array}$ & Max. CIMT \\
\hline $\begin{array}{l}\text { Lorenz et al. } \\
2010\end{array}$ & CAPS $^{15}$ & 5,056 & $19-90$ years & $\begin{array}{l}\text { Combined } \\
\text { endpoint of } \mathrm{MI} \\
\text { and Stroke }\end{array}$ & $\begin{array}{l}\text { CCA, } \\
\text { CB, ICA }\end{array}$ & $\begin{array}{l}\text { HR for CIMT-CCA }>0.79 \mathrm{~mm} \text { vs. } \\
<0.63 \mathrm{~mm} 1.85(1.09-3.15) \text {, } \\
\text { HR for CIMT-CB }>0.79 \mathrm{~mm} \text { vs. } \\
<0.63 \mathrm{~mm} 1.27(0.80-1.99) \text {, } \\
\text { HR for CIMT-ICA }>0.79 \mathrm{~mm} \text { vs. } \\
<0.63 \mathrm{~mm} 1.25(0.84-1.86) \\
\text { (Adjusted for risk factors) }\end{array}$ & $\begin{array}{l}\text { Mean far wall } \\
\text { CIMT }\end{array}$ \\
\hline $\begin{array}{l}\text { Nambi et al. } \\
2010\end{array}$ & $\mathrm{ARIC}^{16}$ & 13,145 & 45-64 years & $\begin{array}{l}\text { Fatal and non-fatal } \\
\mathrm{CV} \text { events and } \\
\text { revascularization }\end{array}$ & $\begin{array}{l}\text { CCA, } \\
\text { CB, ICA }\end{array}$ & $\begin{array}{l}\text { Men: CIMT increased AUC from } \\
0.674 \text { (only risk factors) up to } \\
0.690 \text { (95\% CI for difference of the } \\
\text { adjusted AUC: } 0.009-0.022 \text { ). } \\
\text { Women: CIMT increased AUC } \\
\text { from } 0.759 \text { (only risk factors) up to } \\
0.762 \text { (95\% CI for difference of the } \\
\text { adjusted AUC: }-0.002-0.006 \text { ). }\end{array}$ & $\begin{array}{l}\text { Mean CIMT } \\
\text { from } 6 \\
\text { different } \\
\text { segments }\end{array}$ \\
\hline $\begin{array}{l}\text { Plichart et } \\
\text { al. } 2011\end{array}$ & $\begin{array}{l}\text { Three- } \\
\text { City }^{17}\end{array}$ & 5,895 & $65-85$ years & $\begin{array}{l}\text { Newly diagnosed } \\
\text { CV disease }\end{array}$ & CCA & $\begin{array}{l}\text { HR } 5 \text { th vs. } 1 \text { st quintile }=0.8 ; 95 \% \\
\mathrm{CI}=0.5-1.2 ; \mathrm{P} \text { for trend }<0.48)\end{array}$ & $\begin{array}{l}\text { Mean far wall } \\
\text { CIMT; }\end{array}$ \\
\hline
\end{tabular}

An increased age increases the CIMT value for a person. It has been described that CIMT increases at a rate of 0.007 per year with 5 -year delay in women. ${ }^{18}$

\section{Technique of measurement:}

Ultrasound measurement is safe, cheap, relatively painless and quick way of examination without radiation exposure. Moreover it can be repeated over time and time. At present time $\mathrm{B}$ mode ultrasound can be used to see the artery wall changes via measurement of CIMT and plaques.

Given the technical limitation to image intima alone, combined thickness of intima and media is measured. It is measured as the distance between lumen-intima interface and media-adventitia interface.

Carotid plaques are the localized atherosclerotic substances that build up inside the carotid artery consisting of necrotic cells, lipids and cholesterol crystals. The plaques can cause stenosis, embolism, and thrombosis.

Carotid plaques differ from CIMT by an increase in CIMT about at least $0.5 \mathrm{~mm}$ compared to adjacent wall or increase in thickness more than $50 \%$ to adjacent wall as well as total thickness more than $1.5 \mathrm{~mm}$, much higher value than CIMT alone. ${ }^{19}$

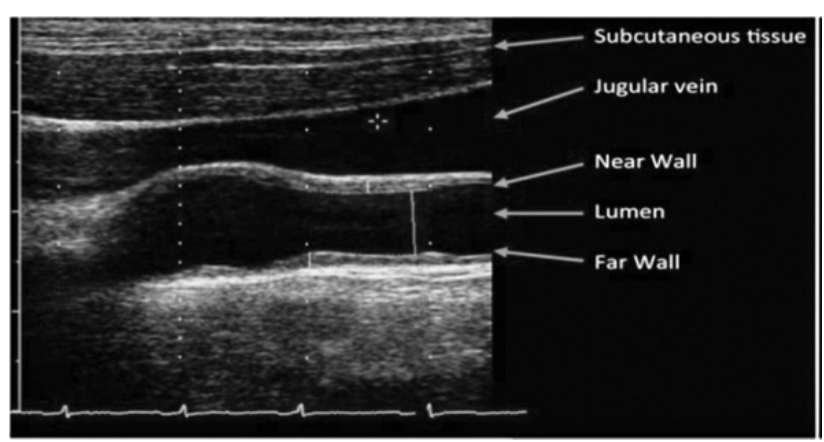

Fig 2: Ultrasound image showing measurement of near and far wall CIMT in the distal $1 \mathrm{~cm}$ of the CCA. ${ }^{7}$ 


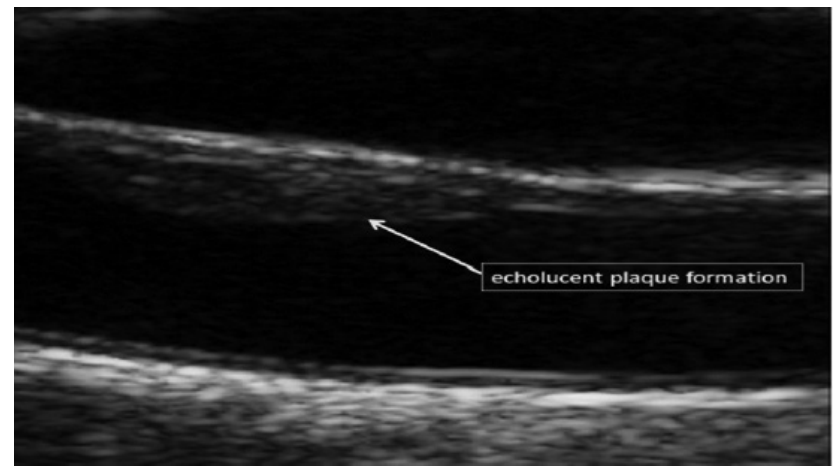

Figure 3: Echolucent carotid plaque formation at the near wall of the common carotid artery

\section{Positioning:}

Both patient and sonographer should be at ease and properly positioned to facilitate high quality reproducible images. Proper imaging requires adequate time and set up of examination room.

The patient will be lying in the supine position with the neck rotated to the opposite side of examination. CCA images are obtained in three different angle views for each vessel from distal $1 \mathrm{~cm}$ of vessel $1 \mathrm{~cm}$ proximal to the carotid bifurcation. The measurement should be taken in both sides.

\section{Instrumentation:}

Examination of the carotid artery wall should be done using state of the art ultrasound system using a linear array transducer at its fundamental frequency of at least $7 \mathrm{MHz}$. Non-fundamental frequency can falsely increase the wall thickness. Use of contrast agent is not recommended. The zoom function is also not be utilized. Most studies can be done at a standard depth of $4 \mathrm{~cm}$; however it may be increased in patients with deep vessels or large necks.

Despite higher temporal resolution with M-mode ultrasound, $\mathrm{B}$-mode imaging is preferred for CIMT measurement. $M$ mode provides measurement along a single point of thickness; perpendicular images is unlikely or challenging; and all reported observational studies relating CIMT values to cardiovascular events have used B-mode imaging.

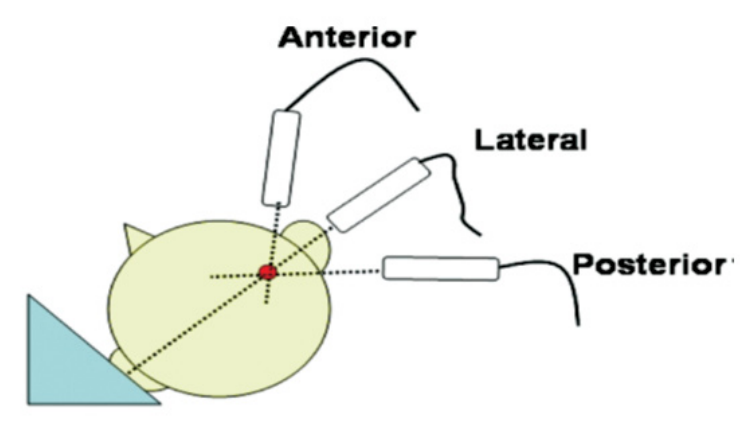

Figure 4: Head position and probe orientation for right CCA imaging

\section{Measurement Protocol:}

The imaging protocol should follow the same method that is applied in large epidemiological study, which reported CIMT values in percentiles by age, sex, and ethnicity such as ARIC study. It is recommended to measure the last $1 \mathrm{~cm}$ of distal CCA. The distal CCA is usually straight and relatively superficial so it is easy to obtain consistent value. The far wall is chosen because it has limited movement, is of good size and is easily accessible; and hence technically easier, more reproducible and improves risk prediction. Several measurements are to be taken and then averaged to get the mean value.

In addition, since ultrasound beams are travelling from more echogenic to less echogenic area in the near wall, CIMT will be less accurate. In fact, one study near wall CIMT was $20 \%$ less than corresponding histology. ${ }^{20}$

A circumferential scan of the extracranial carotid arteries is to be supplemented to find out any carotid plaques that measure more abundant atherosclerotic lesions. ${ }^{21}$

Normal value of CIMT is difficult to obtain because the absolute values depends also on location of measurement (segment of artery, near or far wall), body habitus, ultrasound equipment used, imaging depth, off line recording system (automated or manual tracking), and imaging quality obtained. In general, values of CIMT more than $0.9 \mathrm{~mm}$ are considered abnormal. To be precise, the mean value $>75$ th percentile for the specific age, sex, ethnicity and side should be used.

These values are responsible for variations in CIMT values among different studies. So for the purpose of standardization, the far wall of distal $1 \mathrm{~cm}$ of CCA of both sides should be used in the clinical practice in three different angles and averaged value is to be compared.

\section{Problems and Solution:}

One challenge could be unable to get double line sign so as to define media-adventitia interface. It should be overcome by repeated attempts of imaging in different positions, moving transducers to more horizontal position and changing the focus and gain.

Another issue is tortuosity of CCA. Rotation and elongation of neck will straighten the vessel segment. If excessive respiratory movement is occurring and transition artifact from jugular vein is interfering, breath hold at mid inspiration will stabilize the image and then CIMT could be measured satisfactorily.

Using appropriate gain setting, linear array transducer of at least $7 \mathrm{MHz}$ frequency at its fundamental frequency, proper time gain compensation settings are all important to have reliable and reproducible image.

In fact Velazquez et al reported a very high degree of interobserver correlation $(97.2 \%)$ if we follow the same standard protocol. $^{22}$

\section{Clinical significance of CIMT:}

Multiple epidemiological studies have shown that traditional as well as emerging cardiovascular risk factors are associated with increased CIMT., ${ }^{53-30}$ Age, hypertension, diabetes mellitus, dyslipidemia, smoking all have positive correlation with increased CIMT. Emerging risk factors including lipoprotein (a), oxidized LDL, and homocysteine are also shown to have positive correlation.

Inflammatory markers are associated with atherosclerosis and these markers do correlate with elevated CIMT values. Wang et al showed that elevated CIMT with C-reactive protein in women in Framingham Heart Study, even after adjustment of traditional risk factors. ${ }^{31} \mathrm{C}$-reactive protein was found to be associated with CIMT in Rotterdam study and could predict the progression as well. ${ }^{32}$ The constellation of cardiovascular risks with abdominal obesity, hypertension, hyperglycemia, hypertriglyceridemia, insulin resistance, known as metabolic syndrome has different perspective to CIMT value and is a subject of research. Disproportionate elevation in CIMT is found in patients with metabolic syndrome in a study using data from Baltimore Longitudinal Study of Aging. ${ }^{33}$ Even in young 
population, people with metabolic syndrome had a higher CIMT value compared to control population. ${ }^{34}$

A fact comes to our mind that the artery being imaged is not a coronary artery then how could carotid atherosclerosis predict coronary events. The notion is that atherosclerosis is systemic disease. So coronary atherosclerosis assessed by CT coronary calcification and coronary angiography is found to be associated with increased CIMT and carotid plaques. In Rotterdam Calcification Study, in 2013 patients, carotid intimamedia thickness and coronary calcium scores were significantly associated after adjustment of traditional $\mathrm{CV}$ risk factors including hypertension, diabetes, smoking and dyslipidemia. ${ }^{35}$ In Muscatine study, these findings were found even in young patients of 33-42 years. ${ }^{36}$ CIMT remained to be associated with statistical significance in multivariate analysis. In another study by Kafetzakis et al, there was positive correlation of CIMT and significant coronary artery disease as assessed by coronary angiography having $>50 \%$ diameter stenosis. There was positive association with increased number of coronary artery involved. ${ }^{37}$ 558 patients were evaluated in a study by Kablak-Ziemcicka et al who found that an individual with CIMT value of $>1.15 \mathrm{~mm}$ had a $94 \%$ chance of having significant CAD. ${ }^{38}$

All these findings produced the concept of CIMT as surrogate marker of CAD. We now know that atherosclerosis begins in early age and gradually progresses over years. Because of these long years of development of clinical CV events, occurrence of them takes years of follow up and lengthy expensive use of resources. So CIMT is often used in studies to assess the effect of pharmacological therapy in treatment of cardiovascular disease.

Pitt et al found the effect of amlodipine to regress CIMT whereas verapamil and probucol have been shown to decrease the progression of CIMT in different studies..$^{39-41}$ Metoprolol succinate is also shown to significantly decrease CIMT and trends towards lower $\mathrm{CV}$ events. ${ }^{42}$ Pioglitazone has also to decrease CIMT in diabetic patients. In that study, in 173 diabetic patients, Pioglitazone decreased mean CIMT value by $-54 \pm 59 \mu \mathrm{m}$ at 6 months $(\mathrm{P}<0.001)$ whereas there was no statistical significance with glimepiride. ${ }^{43}$ For mean follow up of 3.6 months, folic acid was not found to change CIMT value in chronic kidney disease patients. $^{44}$

HMG CoA reductase-inhibitors or statin group of drugs has most robust data for changes in CIMT. 919 people with hypercholesterolemia but asymptomatic were studied by Prostfield et al in which lovastatin significantly decreased mean CIMT as well as CV event rate and mortality. ${ }^{45}$ MacMohan et al studied in 552 people with history of CAD but average cholesterol level; pravastatin treated group had $0.014 \mathrm{~mm}$ less CIMT whereas placebo treated group had $0.048 \mathrm{~mm}$ increase in CIMT over a period of 4 years. ${ }^{46}$ Another study showed that more intense statin therapy decreases CIMT more aggressively. Smilde et al studied 325 patients with familial hypercholesterolemia in which $80 \mathrm{mg}$ of atorvastatin decreased CIMT value by -0.031 $\mathrm{mm}(95 \% \mathrm{CI}-0.031$ to $-0.055 ; \mathrm{P}<0.0017)$ after two years of follow up. ${ }^{47}$ In ARBITER (arterial biology for investigations of the treatment effects of reducing cholesterol) trial, Taylor et al used $80 \mathrm{mg}$ atorvastatin that decreased CIMT by $-0.034 \pm 0.021$ mm compared to $40 \mathrm{mg}$ pravastatin $(0.025 \pm 0.017 \mathrm{~mm})(\mathrm{P}<0.03)$ at follow up period of 1 year. ${ }^{48}$ Fibrates do not have same effect on decreasing CIMT values. ${ }^{49}$

\section{The future:}

Although more than three decades already passed since the introduction of CIMT and its ability to predict future cardiovascular risk, it is not widely practiced. Moreover a number of pitfalls exists to make it a quality measurement that is consistent at both inter- and intra-observer level. Many issues regarding extensive imaging protocol can put the cost and available resources in question. Since it is fine measurement, 0.1 $\mathrm{mm}$ measurement differences can put patients in different risk categories, quality control is a definite prerequisite.

One of the best ways to apply cardiovascular prevention is measurement of CIMT in young people. If we can apply correctly about the correct prediction of risk of events before it occurs, we can apply the intense lifestyle and/or pharmacological interventions in the target groups. As views by Urbina et al few issues has to be solved in current CIMT knowledge in young. ${ }^{50}$ These include normative values in young, how to address in regard to body size and growth, and which segment provides best information.

CIMT is used as surrogate marker of cardiovascular events in many clinical trials. For that evidence should show that changes in CIMT should show parallel changes in CV events. Two metaanalyses show conflicting results with this regard. Consistent imaging protocols were not used in both meta-analyses and future studies will help to have definitive conclusion in this matter.

It seems that CIMT hold particular promise to risk categorization for those with intermediate risk using existing risk assessment method such as Framingham risk score. At the outset, the use of CIMT in risk profiling depends on balance between costs and effectiveness (events prevented, life gained, quality adjusted life years gained).

\section{The Back Side:}

Although several studies showed the predictive power of future cardiovascular events, there is little add on prognostic value when CIMT is combined with traditional risk factors score such as Framingham Risk Score. These views have been laid by two meta-analyses. Lorenz et al observed that by $0.1 \mathrm{~mm}$ increase in CIMT relative risk of CV event is increased by $1.15^{51}$. Den Ruijter et al found there is no additional event prediction by adding CIMT to conventional risk factors. ${ }^{52}$

The 2010 ACC/AHA guideline recommended CIMT measurement for CVD risk assessment in intermediate risk asymptomatic patients as class IIa recommendation ${ }^{53}$. However 2013 guideline is against its use for individual risk prediction ${ }^{54}$.

These varying results and guideline recommendations are reflected by different parts of the artery imaged, plaques included or excluded; and the equipment and technical method of measurement. In fact the test had shown higher accuracy and reproducibility in the research settings when appropriately done according to strict protocol, accurate equipment and operator training. But the same is not reproduced in the clinical practice settings. All the available data are from the research studies following highly standardized protocols.

The elevated level of CIMT is regarded as the value exceeding 75 th percentile value of population based study, but it must be identified to a particular carotid artery segment and ultrasound methodology to be used.

$2013 \mathrm{ACC} / \mathrm{AHA}$ guideline tried to search for the evidence of reclassification or contribution of CIMT to the risk assessment to an asymptomatic adult male in routine clinical practice. The final conclusion made by the Work Group was, with concern of measurement quality, there was sufficient rationale to recommend against measuring CIMT in routine clinical practice for estimation of risk for the first cardiovascular events.

It seems that when the technology improves with finer resolution of ultrasound techniques or if we could find the correct way to find asymptomatic atherosclerotic process, which will be boon to the medical practice that would correctly identify those people who are going to have cardiovascular event in near future. Carotid intima media thickness is a promising one but still not yet validated to be useful at the moment. 


\section{References:}

1. McGill Jr HC, McMahan CA, Herderick EE et al. Obesity accelerates the progression of coronary atherosclerosis in young men. Circ 2002;105(23):2712-2718. https://doi. org/10.1161/01.CIR.0000018121.67607.CE

2. Virmani R, Burke AP, Farb A, Kolodgie FD. Pathology of the vulnerable plaque. J Am Coll Cardiol 2006;47(8s1):C13-C18.

3. Greenland P, Abrams J, Aurigemma GP et al. Prevention Conference V: Beyond secondary prevention: identifying the high-risk patient for primary prevention: noninvasive tests of atherosclerotic burden: Writing Group III. Circ 2000;101:E16-E22. https://doi.org/10.1161/01. CIR.101.1.e16

4. Taylor AJ, Merz CNB, Udelson JE. Executive summarycan atherosclerosis imaging techniques improve the detection of patients at risk for ischemic heart disease? J Am Coll Cardiol 2003;41:1860-2. https://doi.org/10.1016/ S0735-1097(03)00363-2

5. Chambless LE, Heiss G, Folsom AR et al. Association of coronary heart disease incidence with carotid arterial wall thickness and major risk factors: the Atherosclerosis Risk in Communities (ARIC) Study, 1987 to 1993. Am J Epidemiol 1997;146:483-94. https://doi.org/10.1093/oxfordjournals. aje.a009302

6. O'Leary DH, Polak JF, Kronmal RA, Manolio TA, Burke GL, Wolfson SK. Carotid-artery intima and media thickness as a risk factor for myocardial infarction and stroke in older adults. Cardiovascular Health Study Collaborative Research Group. N Engl J Med 1999;340:14-22. https:// doi.org/10.1056/NEJM199901073400103

7. Bauer M, Caviezel S, Teynor A, Erbel R, Mahabadi AA, Schmidt-Trucksñss A. Carotid intima-media thickness as a biomarker of subclinical atherosclerosis. Swiss Med Wkly 2012;142:w13705. https://doi.org/10.4414/ smw.2012.13705

8. Faxon DP, Creager MA, Smith SC et al. Atherosclerotic Vascular Disease Conference Executive Summary: Atherosclerotic Vascular Disease Conference Proceeding for Healthcare Professionals From a Special Writing Group of the American Heart Association. Circ 2004;109(21):25952604. https://doi.org/10.1161/01.CIR.0000128517.52533. DB

9. Ross R, Faggiotto A, Bowen-Pope D, Raines E. The role of endothelial injury and platelet and macrophage interactions in atherosclerosis. Circ 1984;70(5 Pt 2):III77.

10. Hansson GrK. Inflammation, atherosclerosis, and coronary artery disease. N Eng J Med 2005;352(16):1685-1695. https://doi.org/10.1056/NEJMra043430

11. Hegele RA. The pathogenesis of atherosclerosis. Clinica chimica acta 1996;246(1):21-38. https://doi. org/10.1016/0009-8981(96)06224-9

12. Johnsen SH, Mathiesen EB. Carotid plaque compared with intima-media thickness as a predictor of coronary and cerebrovascular disease. Curr Cardiol Rep 2009;11(1):2127. https://doi.org/10.1007/s11886-009-0004-1

13. Pignoli P, Tremoli E, Poli A, Oreste P, Paoletti R. Intimal plus medial thickness of the arterial wall: a direct measurement with ultrasound imaging. Circ 1986;74:1399_ 1406. https://doi.org/10.1161/01.CIR.74.6.1399

14. Del Sol AI, Bots ML, Grobbee DE, Hofman A, Witteman JCM. Carotid intima-media thickness at different sites: relation to incident myocardial infarction. The Rotterdam Study. Eur Heart J 2002;23(12):934-940. https://doi. org/10.1053/euhj.2001.2965

15. Lorenz MW, Schaefer C, Steinmetz H, Sitzer M. Is carotid intima media thickness useful for individual prediction of cardiovascular risk? Ten-year results from the Carotid Atherosclerosis Progression Study (CAPS). Eur Heart J 2010;31(16):2041-2048. https://doi.org/10.1093/eurheartj/ ehq189

16. Nambi V, Chambless L, Folsom AR et al. Carotid intimamedia thickness and presence or absence of plaque improves prediction of coronary heart disease risk: the ARIC (Atherosclerosis Risk In Communities) study. J Am Coll Cardiol 2010;55(15):1600-1607. https://doi.org/10.1016/j. jacc.2009.11.075

17. Plichart M, Celermajer DS, Zureik M et al. Carotid intimamedia thickness in plaque-free site, carotid plaques and coronary heart disease risk prediction in older adults. The Three-City Study. Atheroscler 2011;219(2):917-924. https://doi.org/10.1016/j.atherosclerosis.2011.09.024

18. Bauer M, Mhlenkamp S, Lehmann $\mathrm{N}$ et al. The effect of age and risk factors on coronary and carotid artery atherosclerotic burden in males: Results of the Heinz Nixdorf Recall Study. Atheroscler 2009;205(2):595-602. https://doi.org/10.1016/j.atherosclerosis.2009.01.005

19. Touboul PJ, Hennerici MG, Meairs S et al. Mannheim carotid intima-media thickness consensus (2004 to 2006). Cerebrovascular Diseases 2006;23(1):75-80. https://doi. org/10.1159/000097034

20. Wong M, Edelstein J, Wollman J, Bond MG. Ultrasonicpathological comparison of the human arterial wall. Verification of intima-media thickness. Arterioscler Thromb Vasc Biol 1993;13(4):482-486. https://doi. org/10.1161/01.ATV.13.4.482

21. Wyman RA, Fraizer MC, Keevil JG et al. Ultrasounddetected carotid plaque as a screening tool for advanced subclinical atherosclerosis. Am Heart J 2005;150(5):10811085. https://doi.org/10.1016/j.ahj.2005.01.010

22. Velazquez F, Berna JD, Abellan JL, et al. Reproducibility of sonographic measurement of carotid intima-media thickness. Acta Radiol 2008;49:1162-6. https://doi. org/10.1080/02841850802438520

23. Lakka TA, Salonen R, Kaplan GA, Salonen JT. Blood pressure and the progression of carotid atherosclerosis in middle-aged men. Hypertension 1999;34(1):51-56. https:// doi.org/10.1161/01.HYP.34.1.51

24. Wagenknecht LE, D'Agostino R Jr, Savage PJ, O'Leary DH, Saad MF, Haffner SM. Duration of diabetes and carotid wall thickness. The Insulin Resistance Atherosclerosis Study (IRAS). Stroke 1997;28(5):999- 1005. https://doi. org/10.1161/01.STR.28.5.999

25. Diez-Roux AV, Nieto FJ, Comstock GW, Howard G, Szklo $M$. The relationship of active and passive smoking to carotid atherosclerosis 12-14 years later. Prev Med 1995;24(1):48. https://doi.org/10.1006/pmed.1995.1007

26. Juonala M, Viikari JS, Laitinen $\mathrm{T}$ et al. Interrelations between brachial endothelial function and carotid intimamedia thickness in young adults the cardiovascular risk in young Finns study. Circ 2004;110(18):2918-2923. https:// doi.org/10.1161/01.CIR.0000147540.88559.00

27. Durga J, Verhoef P, Bots ML, Schouten E. Homocysteine and carotid intima-media thickness: a critical appraisal of the evidence. Atherosclerosis 2004;176(1):1-20. https://doi. org/10.1016/j.atherosclerosis.2003.11.022

28. Baldassarre D, Tremoli E, Franceschini G, Michelagnoli S, Sirtori CR. Plasma lipoprotein (a) is an independent factor associated with carotid wall thickening in severely but not moderately hypercholesterolemic patients. Stroke 1996;27(6):1044-1049. https://doi.org/10.1161/01. STR.27.6.1044 
29. Wallenfeldt K, Fagerberg Br, Wikstrand J, Hulthe J. Oxidized low-density lipoprotein in plasma is a prognostic marker of subclinical atherosclerosis development in clinically healthy men. J Intern Med 2004;256(5):413-420. https://doi.org/10.1111/j.1365-2796.2004.01402.x

30. Sigurdardottir V, Fagerberg B, Hulthe J. Circulating oxidized low-density lipoprotein (LDL) is associated with risk factors of the metabolic syndrome and LDL size in clinically healthy 58-year-old men (AIR study). J Intern Med 2002;252(5):440. https://doi.org/10.1046/j.13652796.2002.01054.x

31. Wang D, Yang H, Quiones MJ et al. A Genome-Wide Scan for Carotid Artery Intima-Media Thickness The Mexican-American Coronary Artery Disease Family Study. Stroke 2005;36(3):540-545. https://doi.org/10.1161/01. STR.0000155746.65185.4e

32. Van der Meer IM, Bots ML, Hofman A, del Sol AI, van der Kuip DA, Witteman JC. Predictive value of noninvasive measures of atherosclerosis for incident myocardial infarction. Circ 2004;109(9):1089-1094. https://doi. org/10.1161/01.CIR.0000120708.59903.1B

33. Scuteri A, Morrell CH, Najjar SS, Muller D, Andreas R, Ferrucci L, Lakatta EG. Longitudinal Paths to the Metabolic Syndrome: Can the Incidence of the Metabolic Syndrome Be Predicted? The Baltimore Longitudinal Study of Aging. J Gerontol A Biol Sci Med Sci (2009) 64A (5): 590-598. https://doi.org/10.1093/gerona/glp004

34. Tzou WS, Douglas PS, Srinivasan SR, Bond MG, Tang R, Chen W, Berenson GS, Stein GH. Increased Subclinical Atherosclerosis in Young Adults With Metabolic Syndrome. J Am Col Card, 2005; 46 (3): 457-463. https:// doi.org/10.1016/j.jacc.2005.04.046

35. Oei HH, Vliegenthart R, Hak AE et al. The association between coronary calcification assessed by electron beam computed tomography and measures of extracoronary atherosclerosisthe Rotterdam Coronary Calcification Study. J Am Col Card 2002;39(11):1745-1751. https://doi. org/10.1016/S0735-1097(02)01853-3

36. Davis PH, Dawson JD, Mahoney LT, Lauer RM. Increased carotid intimal-medial thickness and coronary calcification are related in young and middle-aged adults: the Muscatine study. Circ 1999;100(8):838-842. https:// doi.org/10.1161/01.CIR.100.8.838

37. Kafetzakis A, Kochiadakis G, Laliotis A et al. Association of subclinical wall changes of carotid, femoral, and popliteal arteries with obstructive coronary artery disease in patients undergoing coronary angiography. Chest 2005;128(4):25382543. https://doi.org/10.1378/chest.128.4.2538

38. Kablak-Ziembicka A, Tracz W, Przewlocki T, Pieniazek P, Sokolowski A, Konieczynska M. Association of increased carotid intima-media thickness with the extent of coronary artery disease. Heart 2004;90(11):1286-1290. https://doi. org/10.1136/hrt.2003.025080

39. Pitt B, Byington RP, Furberg CD et al. Effect of amlodipine on the progression of atherosclerosis and the occurrence of clinical events. Circ 2000;102(13):1503-1510. https://doi. org/10.1136/hrt.2003.025080

40. Zanchetti A, Rosei EA, Dal Pal+i C, Leonetti G, Magnani B, Pessina A. The Verapamil in Hypertension and Atherosclerosis Study (VHAS): results of longterm randomized treatment with either verapamil or chlorthalidone on carotid intima-media thickness. J Hypertens 1998;16(11):1667-1676. https://doi. org/10.1097/00004872-199816110-00014

41. Baldassarre D, Franceschini G, Peruzzotti G, Brusoni B, Sirtori CR. Clinical evaluation of probucol in hypercholesterolemia: Individual lipoprotein responses and inhibitory effect on carotid atherosclerosis progression. J Cardiovasc Pharmacol 1997;30(6):784-789.. https://doi. org/10.1097/00005344-199712000-00013

42. Hedblad B, Wikstrand J, Janzon L, Wedel H, Berglund G. Low-dose metoprolol CR/XL and fluvastatin slow progression of carotid intima-media thickness: main results from the beta-Blocker Cholesterol-Lowering Asymptomatic Plaque Study (BCAPS). Circ 2001;103(13):1721-1726. https://doi.org/10.1161/01.CIR.103.13.1721

43. Pfutzner A, Marx N, Lubbben G et al. Improvement of Cardiovascular Risk Markers by Pioglitazone Is Independent From Glycemic Control Results From the Pioneer Study. J Am Coll Cardiol 2005;45(12):1925-1931. https://doi.org/10.1016/j.jacc.2005.03.041

44. Zoungas S, McGrath BP, Branley P et al. Cardiovascular Morbidity and Mortality in the Atherosclerosis and Folic Acid Supplementation Trial (ASFAST) in Chronic Renal FailureA Multicenter, Randomized, Controlled Trial. J Am Coll Cardiol 2006;47(6):1108-1116. https://doi. org/10.1016/j.jacc.2005.10.064

45. Probstfield JL, Margitic SE, Byington RP, Espeland MA, Furberg CD. Results of the primary outcome measure and clinical events from the Asymptomatic Carotid Artery Progression Study. Am J Cardiol 1995;76(9):47C-53C. https://doi.org/10.1016/S0002-9149(99)80470-6

46. MacMahon S, Sharpe N, Gamble G et al. Effects of lowering average or below-average cholesterol levels on the progression of carotid atherosclerosis: results of the LIPID atherosclerosis substudy. Circ 1998;97(18):17841790. https://doi.org/10.1161/01.CIR.97.18.1784

47. Smilde TJ, Van Wissen S, Awollersheim H, Trip MD, Kastelein JJP, Stalenhoef AFH. Effect of aggressive versus conventional lipid lowering on atherosclerosis progression in familial hypercholesterolemia (ASAP): a prospective, randomised, double-blind trial.Lancet 2001;357(9256):577581. https://doi.org/10.1016/S0140-6736(00)04053-8

48. Taylor AJ, Kent SM, Flaherty PJ, Coyle LC, Markwood TT, Vernalis MN. ARBITER: Arterial Biology for the Investigation of the Treatment Effects of Reducing Cholesterol A Randomized Trial Comparing the Effects of Atorvastatin and Pravastatin on Carotid Intima Medial Thickness. Circ 2002;106(16):2055-2060. https://doi. org/10.1161/01.CIR.0000034508.55617.65

49. Chironi G, Simon A, Gariepy J, Balice M, Del-Pino M, Levenson J. Differential associations of statin and fibrate treatment with carotid arterial remodeling. Am J Hypertens 2005;18(11):1476-1481. https://doi.org/10.1016/j. amjhyper.2005.05.019

50. Urbina EM, Williams RV, Alpert BS, et al. Noninvasive assessment of subclinical atherosclerosis in children and adolescents: recommenda- tions for standard assessment for clinical research: a scientific state- ment from the American Heart Association. Hypertension 2009;54: 919 -50. https:// doi.org/10.1161/HYPERTENSIONAHA.109.192639

51. Lorenz MW, Markus HS, Bots ML, Rosvall M, Sitzer M. Prediction of clinical cardiovascular events with carotid intima-media thickness: a systematic review and metaanalysis. Circ2007;115:459-467. https://doi.org/10.1161/ CIRCULATIONAHA.106.628875

52. Den Ruijter HM, Peters SA, Anderson TJ, Britton AR, Dekker JM, Eijkemans MJ, Engstrom G, Evans GW, de Graaf J, Grobbee DE, Hedblad B, Hofman A, Holewijn S, Ikeda A, Kavousi M, Kitagawa K, Kitamura A, Koffijberg H, Lonn EM, Lorenz MW, Mathiesen EB, Nijpels G, Okazaki S, O'Leary DH, Polak JF, Price JF, Robertson C, Rembold 
CM, Rosvall M, Rundek T, Salonen JT, Sitzer M, Stehouwer CD, Witteman JC, Moons KG, Bots ML. Common carotid intima- media thickness measurements in cardiovascular risk prediction: a meta- analysis. JAMA 2012;308:796-803. https://doi.org/10.1001/jama.2012.9630

53. Greenland P, Alpert JS, Beller GA, Benjamin EJ, Budoff MJ, Fayad ZA, Foster E, Hlatky MA, Hodgson JMcB, Kushner FG, Lauer MS, Shaw LJ, Smith SC, Jr., Taylor AJ, Weintraub WS, Wenger NK. 2010 ACCF/AHA guideline for assessment of cardiovascular risk in asymptomatic adults: a report of the American College of Cardiology Foundation/American Heart Association Task Force on

Cite this article as: Murari Prasad Barakoti. Carotid intima-media thickness and coronary artery Disease. Nepalese Heart Journal 2018; 15(1): 9-15.

http://dx.doi.org/10.3126/njh.v15i1.19705
Practice Guidelines. J Am Coll Cardiol 2010;56:e50-103. https://doi.org/10.1016/j.jacc.2010.09.002

https://doi.org/10.1016/j.jacc.2010.09.001

54. Goff DC Jr, Lloyd-Jones DM, Bennett G, Coady S, D'Agostino RB Sr, Gibbons R, Greenland P, Lackland DT, Levy D, O'Donnell CJ, Robinson JG, Schwartz JS, Shero ST, Smith SC Jr, Sorlie P, Stone NJ, Wilson PWF. 2013 ACC/ AHA guideline on the assessment of cardiovascular risk: a report of the American College of Cardiology/ American Heart Association Task Force on Practice Guidelines. J Am Coll Cardiol 2014;63:2935-59. https:// doi.org/10.1016/j.jacc.2013.11.005 